\title{
Indications and Outcomes After Ligamentum Teres Reconstruction: A Systematic Review
}

\author{
Derrick M. Knapik, M.D., Daniel Farivar, B.S., Kyle N. Kunze, M.D., Ron Gilat, M.D., \\ Shane J. Nho, M.D., and Jorge Chahla, M.D., Ph.D.
}

\begin{abstract}
Purpose: To systematically review the literature to better understand the current indications for ligamentum teres reconstruction (LTR), current graft and acetabular fixation options used, patient-reported outcomes after LTR, and incidence of complications and reoperations after LTR. Methods: A systematic review was conducted according to the Preferred Reporting Items for Systematic Reviews and Meta-analyses (PRISMA) statement. All literature related to LTR published prior to July 2020 was identified. The inclusion criteria consisted of investigations reporting on human patients with pathology of the ligamentum teres who underwent LTR, including mentions of the indications, graft type, acetabular fixation method, postoperative patient-reported outcome scores, and incidence of complications and reoperations. Results: Seven studies comprising 26 patients (28 hips) were included. The most commonly reported indication for LTR was persistent pain and instability after failed prior hip arthroscopy (68\%, 19 of 28 hips). The mean postoperative modified Harris Hip Score, Non-arthritic Hip Score, and visual analog scale score all showed improvement when compared with preoperative values. A total of 2 complications occurred. Complication rates ranged from $0 \%$ to $100 \%$ in included case reports and $0 \%$ to $11 \%$ in included case series. A total of 9 reoperations were performed. Reoperation rates ranged from $0 \%$ to $100 \%$ for case reports and $18 \%$ to $100 \%$ for case series. Reoperation rates ranged from $33 \%$ to $100 \%$ in studies with patients receiving acetabular fixation using anchors versus $0 \%$ to $22 \%$ in studies performing LTR with buttons. Reoperation rates in athletic patients and patients with Ehlers-Danlos syndrome ranged from $0 \%$ to $100 \%$ and $0 \%$ to $50 \%$, respectively. Conclusions: The main indication for LTR was persistent hip or groin pain and instability after a prior hip arthroscopy. The short-term postoperative modified Harris Hip Score, Non-arthritic Hip Score, and visual analog scale score after LTR showed favorable outcomes. However, reoperations after LTR were not uncommon. Level of Evidence: Level V, systematic review of Level IV and V studies.
\end{abstract}

$\mathbf{T}$ he increased popularity and application of hip arthroscopy have led to recent anatomic, biomechanical, and clinical investigations revealing the ligamentum teres (LT), originally believed to be a vestigial structure, to serve an important biomechanical and neurologic function within the hip. ${ }^{1,2}$ As an intraarticular, extra-synovial ligament, the LT arises from

From Midwest Orthopaedics at Rush University, Chicago, Illinois, U.S.A. (D.M.K., K.N.K., R.G., S.J.N., J.C.); and Rush University School of Medicine, Chicago, Illinois, U.S.A. (D.F., K.N.K., S.J.N., J.C.).

The authors report the following potential conflicts of interest or sources of funding: S.J.N. receives research support from Allosource, Arthrex, Athletico, DJ Orthopaedics, Linvatec, Miomed, Smith $\theta$ Nephew, and Stryker; receives intellectual property royalties from Ossur and Stryker; is a paid consultant for Stryker; receives publishing royalties and financial support from Springer; and receives travel and lodging, education support, and food and beverage from Stryker. J.C. is a paid consultant for Arthrex, ConMed Linvatec, Ossur, and Smith $\theta$ Nephew; received education payments from Arthrex (20182019) and Smith $\theta$ Nephew (2018-2019); received consulting fees from DePuy Synthes Products (2019), Linvatec (2019), and Smith $\theta$ Nephew (2019); received speaking fees from Linvatec (2019); and received hospitality payments the transverse acetabular ligament and inferior aspect of the cotyloid fossa, inserting into the fovea capitis on the posterosuperior aspect of the femoral head. ${ }^{3-5}$ For patients with hip microinstability, characterized by the presence of osseous risk factors for instability (acetabular dysplasia, femoroacetabular impingement [FAI], and inferior acetabular deficiency) and

from Medical Device Business Services (2019), Medwest Associates (2019), and Stryker (2019). Full ICMJE author disclosure forms are available for this article online, as supplementary material.

Received August 23, 2020; accepted January 27, 2021.

Address correspondence to Derrick M. Knapik, M.D., Midwest Orthopaedics at Rush University, 1611 W Harrison Ave, Ste 300, Chicago, IL 60612, U.S.A. E-mail: derrick.knapik@gmail.com

(C) 2021 THE AUTHORS. Published by Elsevier Inc. on behalf of the Arthroscopy Association of North America. This is an open access article under the CC BY-NC-ND license (http://creativecommons.org/licenses/by-nc-nd/4.0/). 2666-061X/201443

https://doi.org/10.1016/j.asmr.2021.01.023 
deficiency of the surrounding soft-tissue stabilizing structures (acetabular labrum and hip capsule), the LT functions as an important stabilizer of the hip, primarily in hip flexion and external rotation, as well as hip extension and internal rotation. ${ }^{1,2,6}$ The LT has also been reported to contain a high density of proprioceptive and nociceptive nerve endings, ${ }^{7,8}$ serving as a pain generator in the presence of LT injury. ${ }^{5,6}$

Injuries to the LT have been reported to occur due to acute trauma during hip dislocations ${ }^{9-11}$ or from chronic overuse in athletic patients participating in activities requiring supraphysiological range of motion of the hip. ${ }^{12,13}$ Recent investigations have reported a prevalence of LT pathology occurring in $43 \%$ to $51 \%$ of consecutive patients undergoing hip arthroscopy, ${ }^{1,7,14-17}$ with higher rates in patients with bony abnormalities and ligamentous laxity contributing to hip microinstability. ${ }^{6,18-21}$ Moreover, the prevalence of complete LT tears has been reported to range from $1 \%$ to $26 \%, 1,7,13-15,19,22$ with complete tears being more common in patients with greater severity of bony deformity. ${ }^{17,23}$ Studies to date have rarely found LT tears to occur in isolation and have instead suggested LT tears to represent an end-stage consequence of pathomechanical changes occurring within the hip due to concurrent bony and soft-tissue pathology. $6,7,17,24$

In patients with microinstability with partial or complete LT tears undergoing hip arthroscopy, treatment is generally directed at correction of bony impingement, labral pathology, and capsular laxity, with LT debridement shown to yield satisfactory results. ${ }^{2,18,25}$ However, for a small subset of patients with LT tears and persistent symptoms of pain and hip microinstability after hip arthroscopy, LTR may be indicated to restore hip stability and alleviate pain. ${ }^{2,26}$ As a technically demanding procedure without welldefined indications, there remains a paucity of investigations reporting on clinical outcomes after ligamentum teres reconstruction (LTR). A prior review performed by de Sa et al. ${ }^{18}$ from 2014 reported on outcomes in 6 patients from 3 studies undergoing LTR; however, analysis was limited because of the low number of identified cases. Our current understanding of the LT and the therapeutic benefits of LT repair is still largely speculative; thus, the presentation of any new evidence is warranted.

The purpose of this study was to systematically review the literature to better understand the current indications for LTR, current graft and acetabular fixation options used, patient-reported outcomes (PROs) after LTR, and incidence of complications and reoperations after LTR. We hypothesized that continued instability after prior arthroscopy would be the most common indication, with patients reporting improvement after LTR with few complications and reoperations.

\section{Methods}

\section{Data Sources and Searches}

A systematic review was conducted according to PRISMA (Preferred Reporting Items for Systematic Reviews and Meta-analyses) guidelines using a PRISMA checklist. ${ }^{27}$ All literature pertaining to the performance of LTR published from inception to July 2020 was identified. Two authors - an orthopaedic surgery fellow (D.M.K.) and a medical student (D.F.) - independently conducted a literature search in July 2020 using the following databases: PubMed, Embase, MEDLINE, Biosis Previews, SPORTDiscus, Ovid, PEDRO, and Cochrane Library. Each search included various combinations of the following terms: "ligamentum teres," "reconstruction," "hip," "arthroscopy," and "instability." Systematic review registration was submitted (submission ID CRD42020199366) in July 2020 using the PROSPERO international prospective register of systematic reviews.

\section{Selection Criteria}

The predefined eligibility criteria consisted of investigations reporting on human patients with pathology of the LT who underwent LTR with the reported indications, graft type, acetabular fixation method, postoperative outcomes, and incidence of complications and reoperations. Articles written in English or those with English-language translation were included. Because of the small number of studies identified, no limitation on the number of patients or minimum follow-up time was applied. The exclusion criteria consisted of non-English-language articles; technique, review, or editorial articles; studies documenting hip arthroscopy procedures without LTR; studies reporting on outcomes after LT debridement; and studies not reporting on outcomes after surgery. Investigations from the same institutions were separately reviewed to identify studies likely reporting on the same cohort of patients. When these were identified, the most comprehensive and recent study was included whereas the rest were omitted after discussion with the senior author (J.C.).

\section{Data Extraction and Quality Assessment}

The literature search was performed by sequentially screening articles in the following systematic approach: assessment of duplicate articles, content within the article title, content of the abstract, and full-text review. Full-text review was performed during the study selection process, if necessary, to determine whether the articles satisfied the inclusion and exclusion criteria. To ensure that all available studies were identified, references cited in the included articles were crossreferenced for inclusion of any studies overlooked during the initial search. 
The following data were extracted from the selected studies: year of publication, level of evidence, patient demographic characteristics, indications for LTR, graft type and acetabular fixation method used during LTR, concomitant procedures, PRO scores, complications, and future surgical procedures. The 2 aforementioned authors (D.M.K. and D.F.) quantitatively assessed the quality of studies using the Methodological Index for Non-randomized Studies (MINORS) criteria. $^{28}$ The MINORS scale is a validated list of 8 questions, with 4 additional questions for comparative studies, with each question receiving a score between 0 and 2: 0 , not reported; 1 , reported but inadequate; or 2, reported and adequate. Because no comparative studies evaluating LTR exist and thus none were included in this systematic review, the included studies were assessed using only the first 8 questions, for a maximum score of 16. A high-quality MINORS score will have a clearly stated study aim, inclusion of consecutive patients, prospective collection of data, an appropriate endpoint to the study aim, unbiased evaluation of endpoints, an appropriate follow-up period, a rate of loss to follow-up not exceeding $5 \%$, and prospective calculation of the study sample size. Differences in MINORS score greater than 1 point would have been resolved by mutual discussion between the authors; however, this was not required for any study.

\section{Statistical Analysis}

Because of the lack of comparative studies that exist on LTR, pooling of the data was not performed given that such analyses would potentially result in invalid conclusions. Additionally, heterogeneity of included studies as evidenced by differences in graft type, acetabular fixation, concomitant procedures, and patient comorbidities, as well as variable reporting of functional and clinical outcomes, further precluded meta-analysis and quantitative estimates. When appropriate, data were presented with ranges and frequencies, whereas data not amenable to this presentation were described narratively. All forest plots were produced via OpenMetaAnalyst, using Metafor console code $^{29}$ for the R package (R Foundation for Statistical Computing, Vienna, Austria) and presented without pooled summary estimates.

\section{Results}

After the search of the literature by the 2 independent authors (D.M.K. and D.F.), 810 citations were identified. The search process is shown in the flow diagram (Fig 1). After screening, 22 articles were selected for further evaluation. No disagreements in study selection were encountered. Of these studies, 15 were excluded for the following reasons: technique article $(\mathrm{n}=7)$, review article $(n=3)$, absence of outcomes after LTR $(\mathrm{n}=2)$, study reporting data on identical cohort of patients $(\mathrm{n}=1),{ }^{30}$ and editorial $(\mathrm{n}=1)$. After application of the inclusion and exclusion criteria, 7 studies met the inclusion criteria, comprising 3 case series $^{26,30,31}$ and 4 case reports, ${ }^{11,32-34}$ consisting of a total of 26 patients ( 28 hips) who underwent LTR with a mean follow-up period of 24.2 months (range, 8-48 months) (Table 1). All 3 case series stated that they retrospective reviewed prospectively collected data, whereas the 4 case reports did not report on their methods. Furthermore, only the study by O'Donnell et al. ${ }^{31}$ used specific inclusion and exclusion criteria to account for potential confounding variables, whereas some studies included all patients receiving LTR performed by the authors. ${ }^{26,30}$ No study involved the use of any comparison groups. Furthermore, the average MINORS score was 8.7, with only 1 of the 7 studies having a MINORS score greater than 13, whereas 4 $(57.1 \%)$ had a MINORS score of 6 , indicating a high risk of bias and poor methodology (Table 2). The weaknesses in most of these studies included retrospective data collection, an inability to blind observers, and an insufficient follow-up period.

Two patients from a single study underwent bilateral LTR with subsequent procedures performed at a mean of 4 months (range, 2-6 months) from the initial operation. ${ }^{30}$ The mean patient age at the time of surgery was $30.6 \pm 9.6$ years; patient age was not reported in 1 study. ${ }^{32}$ Eighty-eight percent of patients (22 of 25) were female patients. LTR was performed as a revision procedure in $68 \%$ of hips ( 19 of 28 ) with persistent hip or groin pain despite prior hip arthroscopy. Semitendinosus autograft (13 hips) and tibialis anterior allograft (6 hips) were the most commonly used graft sources during LTR, whereas graft fixation to the acetabulum was performed using a button in 4 studies $^{11,30,33,34}$ and anchors in 3 studies. ${ }^{26,31,32}$ Capsular plication (11 hips) and labral repair (10 hips) were the most commonly performed concomitant procedures during LTR.

The most commonly reported indications for LTR were pain and instability. Among patients from the included studies, only 11 had some form of preoperative imaging reported. In the case report by Hammarstedt et al., ${ }^{33}$ no radiographic measures for instability were found besides slight femoral anteversion of $24^{\circ}$, as well as a labral tear. In another case report, White et al. ${ }^{11}$ reported significant radiographic findings of a low overall acetabular volume with heterotopic ossification, cam-type FAI, an alpha angle exceeding $60^{\circ}$, and a labral tear. In a case report of 9 patients undergoing LTR by Rosinsky et al., ${ }^{30}$ the lateral center-edge angle, anterior center-edge angle, and acetabular inclination were measured radiographically, with no patients possessing values indicative of instability.

The modified Harris Hip Score (mHHS) was reported in 23 hips and in all but 1 study, ${ }^{34}$ showing 


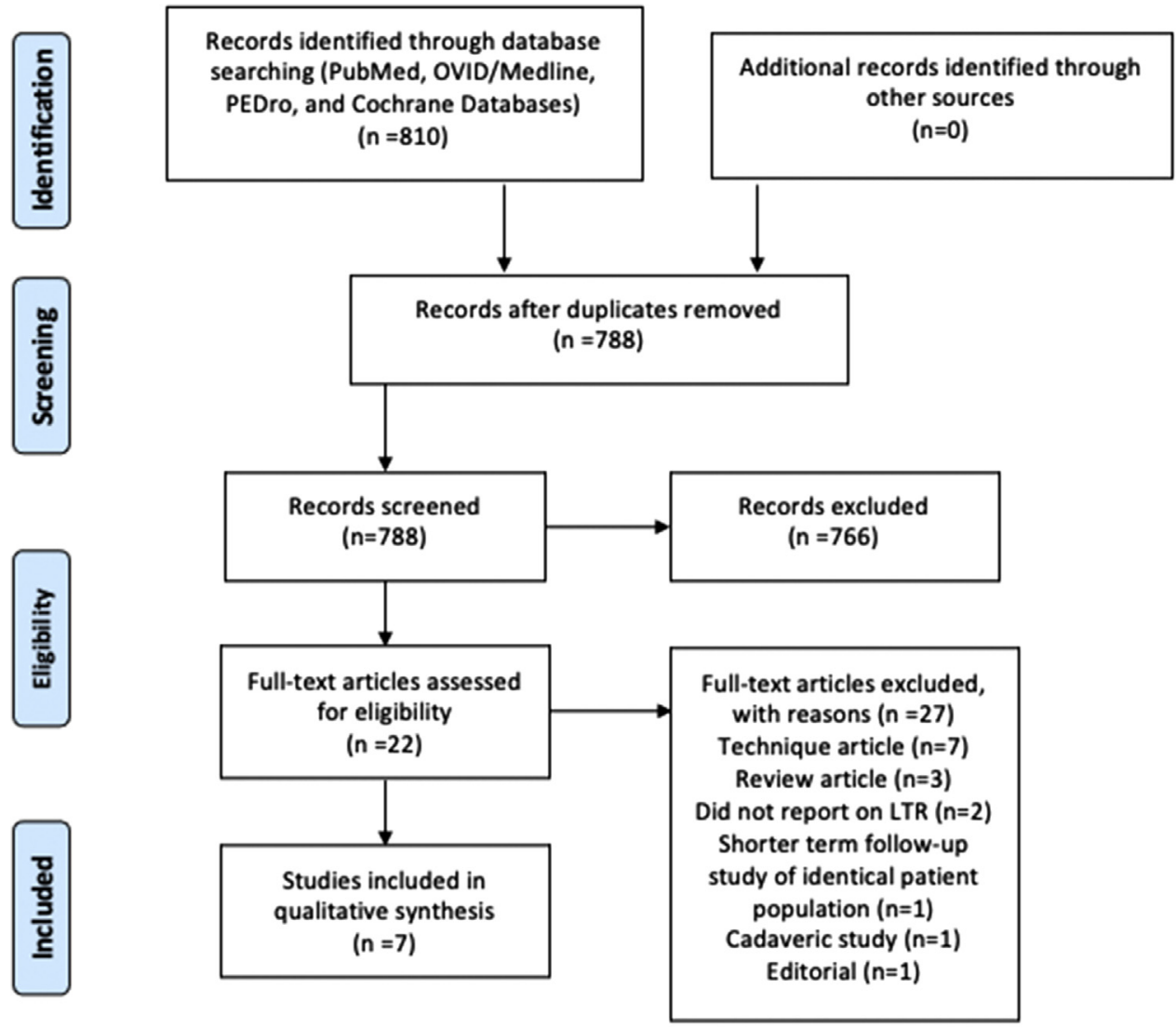

Fig 1. Preferred Reporting Items for Systematic Review and Metaanalyses (PRISMA) guidelines for included studies. (LT, ligamentum teres.) improvement after LTR when comparing postoperative (68-100) with preoperative (36.3-70.4) scores (Table 3). The Non-arthritic Hip Score (NAHS) was reported in 12 hips from 4 studies and improved between the preoperative (24-73) and postoperative (50-95) time points, ${ }^{30,32-34}$ whereas the visual analog scale (VAS) score was reported in 3 studies on 11 hips, ${ }^{11,30,33}$ improving from preoperatively (3.6-10) to postoperatively (0-10). A total of 2 complications were reported ( 2 of 28 hips, $7.1 \%$ ): labial blisters due to traction, which resolved spontaneously, ${ }^{31}$ and a suture abscess requiring arthroscopic removal 15 months after LTR. $^{32}$ A total of 9 reoperations (9 of 28 hips, $32.1 \%$ ) were performed after LTR among patients reported in all 7 studies (Fig 2). The complication rates ranged from $0 \%$ ( 0 of 1 ) to $100 \%$ ( 1 of 1 ) in included case reports and from $0 \%$ ( 0 of 11 ) to $11 \%$ ( 1 of 9 ) in included case series. The reasons for reoperation included conversion to total hip arthroplasty, second-look arthroscopy, lysis of adhesions, iliopsoas tendon release, and joint irrigation for infection. The reoperation rates ranged from $0 \%(0$ of 1$)$ to $100 \%$ ( 1 of 1 ) for case reports and from $18 \%$ (2 of 11 ) to $100 \%$ (3 of 3 ) for case series (Fig 2). Studies with patients receiving acetabular fixation using anchors reported reoperation rates ranging from $33 \%$ (3 of 9) to $100 \%$ (3 of 3), whereas studies performing
LTR with buttons reported reoperation rates ranging from $0 \%$ ( 0 of 1 ) to $22 \%$ (2 of 9) (Fig 3). Patients reported to be athletic experienced reoperation rates ranging from $0 \%$ (0 of 1 ) to $100 \%$ (3 of 3 ), whereas those not reported to be athletic showed reoperation rates ranging from $0 \%$ (0 of 1) to 33\% (3 of 9) (Fig 4). Finally, patients with Ehlers-Danlos syndrome (EDS) and their non-EDS counterparts were reported to have reoperation rates ranging from $0 \%$ (0 of 1 ) to $50 \%$ (2 of 4) and from $0 \%$ (0 of 5) to $100 \%$ (3 of 3), respectively (Fig 5).

\section{Discussion}

The main findings from this study were that the most common indication for LTR was persistent hip or groin pain and instability after prior hip arthroscopy. PROs, such as the mHHS, NAHS, and VAS score, were found to improve in patients after LTR. Although LTR is an increasingly recognized procedure, the literature on LTR remains scarce and available studies are of a low level of evidence. Thus, at this point, the current evidence does not support or discourage the use of LTR.

Reoperations after LTR were more common in patients treated with anchors for acetabular graft fixation when compared with buttons. Multiple studies have recommended that acetabular fixation be placed in the 
Table 1. Overview of Included Studies

\begin{tabular}{|c|c|c|c|c|c|c|c|c|c|}
\hline Study & $\begin{array}{l}\text { Journal } \\
\text { (Year) }\end{array}$ & LOE & $\begin{array}{c}\text { No. of } \\
\text { Patients } \\
\text { (No. of Hips) } \\
\text { [Sex] }\end{array}$ & $\begin{array}{l}\text { Mean Patient } \\
\text { Age (Range), yr }\end{array}$ & Indications & Graft Type & $\begin{array}{c}\text { Acetabular Fixation } \\
\text { Method }\end{array}$ & $\begin{array}{l}\text { Concomitant } \\
\text { Procedures }\end{array}$ & $\begin{array}{l}\text { Mean } \\
\text { Follow-up } \\
\text { (Range), mo }\end{array}$ \\
\hline Rosinsky et al. ${ }^{30}$ & $\begin{array}{c}\text { Arthroscopy } \\
(2020)\end{array}$ & IV & $\begin{array}{l}9(11)[7 \mathrm{~F} \\
\text { and } 2 \mathrm{M}]\end{array}$ & $30.3(20.4-36.8)$ & $\begin{array}{l}\text { Hip pain and MDI with } \\
\text { associated complete or } \\
\text { nearly complete LT tear } \\
(>50 \%)(\mathrm{n}=6) \\
\text { Persistent hip pain and } \\
\text { instability despite prior hip } \\
\text { arthroscopy }(\mathrm{n}=3)\end{array}$ & $\begin{array}{l}\text { ST autograft }(7 \\
\text { of } 11) \\
\text { TA allograft } \\
(4 \text { of } 11)\end{array}$ & $\begin{array}{l}\text { BicepsButton* or } \\
\text { RetroButton* }\end{array}$ & $\begin{array}{l}\text { Labral repair ( } 9 \text { of } \\
11 \text { ) } \\
\text { Labral } \\
\text { debridement ( } 2 \text { of } \\
11 \text { ) } \\
\text { Capsular plication } \\
\text { (10 of } 11 \text { ) } \\
\text { Capsular release } \\
\text { (1 of } 11 \text { ) } \\
\text { Femoroplasty ( } 7 \\
\text { of } 11) \\
\text { Acetabuloplasty } \\
\text { ( } 3 \text { of } 11 \text { ) } \\
\text { Iliopsoas release } \\
\text { (2 of } 11 \text { ) }\end{array}$ & $44.3(24-72)$ \\
\hline $\begin{array}{l}\text { O'Donnell } \\
\text { et al. }^{31}\end{array}$ & $\begin{array}{l}\text { J Hip Preserv } \\
\quad \text { Surg } \\
(2020)\end{array}$ & IV & 9 (9) [all F] & $30(22-48)$ & $\begin{array}{l}\text { Hip pain and instability after } \\
\text { prior arthroscopic LT } \\
\text { excision with capsule } \\
\text { plication }(\mathrm{n}=9)\end{array}$ & $\begin{array}{l}\text { ST autograft }(5 \\
\text { of } 9) \\
\text { TP allograft } \\
(4 \text { of } 9)\end{array}$ & $\begin{array}{l}\text { Knotted anchor } \times 2 \\
\quad(2.9-\mathrm{mm} \\
{\text { Osteoraptor })^{\dagger}}^{\dagger}\end{array}$ & None & $48(12-72)$ \\
\hline White et al. ${ }^{11}$ & $\begin{array}{l}\text { J Hip Preserv } \\
\text { Surg } \\
(2018)\end{array}$ & V & $1(1)[M]$ & 15 & $\begin{array}{l}\text { Hip pain and instability after } \\
\text { posterior hip dislocation } \times 2 \\
(\mathrm{n}=1)\end{array}$ & $\begin{array}{l}\text { TA allograft (1 } \\
\text { of } 1)\end{array}$ & Button (ToggleLoc) ${ }^{\ddagger}$ & $\begin{array}{l}\text { Labral } \\
\text { reconstruction } \\
\text { and femoral } \\
\text { osteoplasty (1 of } \\
\text { 1) }\end{array}$ & 14 \\
\hline $\begin{array}{l}\text { Hammarstedt } \\
\text { et al. }\end{array}$ & $\begin{array}{l}\text { Hip Int } \\
\quad(2015)\end{array}$ & V & $1(1)[F]$ & 43 & $\begin{array}{l}\text { Persistent hip or groin pain } \\
\text { with evidence of instability } \\
(\mathrm{n}=1)\end{array}$ & $\begin{array}{l}\text { TA allograft (1 } \\
\text { of } 1 \text { ) }\end{array}$ & Button & $\begin{array}{l}\text { Labral repair and } \\
\text { capsular plication } \\
(1 \text { of } 1)\end{array}$ & 12 \\
\hline Philippon et al. ${ }^{26}$ & $\begin{array}{l}J \text { Bone Joint } \\
\text { Surg Br } \\
(2012)\end{array}$ & IV & 4 (4) [all F] & $36(30-41)$ & $\begin{array}{l}\text { Persistent hip pain with } \\
\text { instability despite prior hip } \\
\text { arthroscopy }(\mathrm{n}=4)\end{array}$ & $\begin{array}{l}\text { ITB autograft } \\
(4 \text { of } 4)\end{array}$ & $\begin{array}{l}\text { Knotted anchor } \times 1 \\
(2.9 \text {-mm } \\
\text { Osteoraptor })^{\dagger}\end{array}$ & None & $31(6-60)$ \\
\hline $\begin{array}{c}\text { Amenabar and } \\
\text { O'Donnell }\end{array}$ & $\begin{array}{l}\text { Arthrosc Tech } \\
\quad \text { (2012) }\end{array}$ & V & $1(1)[F]$ & NR & $\begin{array}{l}\text { Persistent hip pain with } \\
\text { instability despite prior hip } \\
\text { arthroscopy }(\mathrm{n}=1)\end{array}$ & $\begin{array}{l}\text { ST autograft (1 } \\
\text { of } 1 \text { ) }\end{array}$ & $\begin{array}{l}\text { Knotted anchor } \times 1 \\
(2.3 \text {-mm } \\
\text { Bioraptor })^{\dagger}\end{array}$ & None & 12 \\
\hline Simpson et al. ${ }^{34}$ & $\begin{array}{l}\text { Arthroscopy } \\
\text { (2011) }\end{array}$ & V & $1(1)[F]$ & 20 & $\begin{array}{l}\text { Persistent hip pain with } \\
\text { instability despite prior hip } \\
\text { arthroscopy }(\mathrm{n}=1)\end{array}$ & $\begin{array}{l}\text { Artificial MCL } \\
\operatorname{graft}^{5}(1 \text { of } 1)\end{array}$ & 6-mm cortical ${ }^{\dagger}$ & None & 8 \\
\hline
\end{tabular}

F, female patient; ITB, iliotibial band; LARS, Ligament Augmentation and Reconstruction System; LOE, level of evidence; LT, ligamentum teres; MDI, multidirectional instability, NR, not recorded; M, male patient; MCL, medial collateral ligament; ST, semitendinosus; TA, tibialis anterior; TP, tibialis posterior.

*Arthrex, Naples, Florida.

${ }^{\dagger}$ Smith \& Nephew, London, England.

${ }^{\ddagger}$ Zimmer Biomet, Warsaw, Indiana.

${ }^{\S}$ LARS, Arcsur, Tille, France. 
Table 2. MINORS Scores and Study Design Evaluations of Included Studies

\begin{tabular}{|c|c|c|c|c|c|c|c|c|c|c|}
\hline Study (Year) & $\begin{array}{l}\text { Stated } \\
\text { Aim } \\
\text { of Study }\end{array}$ & $\begin{array}{l}\text { Inclusion of } \\
\text { Consecutive } \\
\text { Patients }\end{array}$ & $\begin{array}{l}\text { Prospective } \\
\text { Collection } \\
\text { of Data }\end{array}$ & $\begin{array}{l}\text { Endpoint } \\
\text { Appropriate to } \\
\text { Study Aim }\end{array}$ & $\begin{array}{l}\text { Unbiased } \\
\text { Evaluation of } \\
\text { Endpoints }\end{array}$ & $\begin{array}{l}\text { Follow-up Period } \\
\text { Appropriate to } \\
\text { Major Endpoint }\end{array}$ & $\begin{array}{l}\text { Loss to } \\
\text { Follow-up Not } \\
\text { Exceeding 5\% }\end{array}$ & $\begin{array}{l}\text { Prospective } \\
\text { Calculation of } \\
\text { Sample Size }\end{array}$ & $\begin{array}{l}\text { Cumulative } \\
\text { MINORS } \\
\text { Score }\end{array}$ & $\begin{array}{c}\text { Additional Study } \\
\text { Design Characteristics }\end{array}$ \\
\hline \multirow[t]{2}{*}{$\begin{array}{l}\text { Rosinsky et al. }{ }^{30} \\
(2020)\end{array}$} & \multirow[t]{2}{*}{2} & \multirow[t]{2}{*}{2} & \multirow[t]{2}{*}{2} & \multirow[t]{2}{*}{2} & \multirow[t]{2}{*}{0} & \multirow[t]{2}{*}{2} & \multirow[t]{2}{*}{1} & \multirow[t]{2}{*}{0} & \multirow[t]{2}{*}{11} & $\begin{array}{l}\text { Retrospectively } \\
\text { reviewed } \\
\text { prospectively } \\
\text { collected data }\end{array}$ \\
\hline & & & & & & & & & & $\begin{array}{l}\text { 2. All patients } \\
\text { undergoing LTR } \\
\text { included }\end{array}$ \\
\hline \multirow[t]{2}{*}{$\begin{array}{l}\text { O'Donnell } \\
\text { et al. }^{31}(2020)\end{array}$} & \multirow[t]{2}{*}{2} & \multirow[t]{2}{*}{2} & \multirow[t]{2}{*}{2} & \multirow[t]{2}{*}{2} & \multirow[t]{2}{*}{1} & \multirow[t]{2}{*}{1} & \multirow[t]{2}{*}{2} & \multirow[t]{2}{*}{0} & \multirow[t]{2}{*}{12} & $\begin{array}{l}\text { Retrospectively } \\
\text { reviewed } \\
\text { prospectively } \\
\text { collected data }\end{array}$ \\
\hline & & & & & & & & & & $\begin{array}{l}\text { 2. Specific inclusion } \\
\text { and exclusion } \\
\text { criteria used }\end{array}$ \\
\hline $\begin{array}{l}\text { White et al. }{ }^{11} \\
\qquad(2018)\end{array}$ & 2 & NA & 0 & 2 & 1 & 1 & NA & NA & 6 & \\
\hline $\begin{array}{l}\text { Hammarstedt } \\
\text { et al. }{ }^{33}(2015)\end{array}$ & 2 & NA & 0 & 2 & 1 & 1 & NA & NA & 6 & \\
\hline \multirow[t]{2}{*}{$\begin{array}{l}\text { Philippon et al. } \\
\text { (2012) }\end{array}$} & \multirow[t]{2}{*}{2} & \multirow[t]{2}{*}{2} & \multirow[t]{2}{*}{2} & \multirow[t]{2}{*}{2} & \multirow[t]{2}{*}{1} & \multirow[t]{2}{*}{2} & \multirow[t]{2}{*}{2} & \multirow[t]{2}{*}{0} & \multirow[t]{2}{*}{13} & \multirow{2}{*}{$\begin{array}{l}\text { 1. Retrospectively } \\
\text { reviewed } \\
\text { prospectively } \\
\text { collected data } \\
\text { 2. All patients } \\
\text { undergoing LTR } \\
\text { included }\end{array}$} \\
\hline & & & & & & & & & & \\
\hline $\begin{array}{l}\text { Amenabar and } \\
\text { O'Donnell } \\
\text { (2012) }\end{array}$ & 2 & NA & 0 & 2 & 1 & 1 & NA & NA & 6 & \\
\hline $\begin{array}{l}\text { Simpson et al. } \\
\text { (2011) }\end{array}$ & 2 & NA & 0 & 2 & 1 & 1 & NA & NA & 6 & \\
\hline
\end{tabular}


Table 3. Patient Outcomes After Ligamentum Teres Reconstruction

\begin{tabular}{|c|c|c|c|c|c|c|c|c|}
\hline \multirow[b]{2}{*}{ Study (Year) } & \multicolumn{2}{|c|}{ Mean mHHS } & \multicolumn{2}{|c|}{ Mean NAHS } & \multicolumn{2}{|c|}{ Mean VAS Score } & \multirow[b]{2}{*}{ Complications } & \multirow[b]{2}{*}{ Reoperations } \\
\hline & Preoperative & Postoperative & Preoperative & Postoperative & Preoperative & Postoperative & & \\
\hline $\begin{array}{l}\text { Rosinsky et al. }^{30} \\
(2020)\end{array}$ & $44.17 \pm 17.7$ & $71.8 \pm 22.7$ & $47.5 \pm 20.6$ & $78.6 \pm 14.6$ & $7.8 \pm 1.2$ & $3.6 \pm 3.6$ & None & $\begin{array}{l}\text { Conversion to THA } \\
(\mathrm{n}=2)\end{array}$ \\
\hline $\begin{array}{l}\text { O'Donnell }^{\prime} \text { et al. }{ }^{31}(2020) \\
\text { (2) }\end{array}$ & $\begin{array}{l}51.5 \pm 9.4 \\
\quad(\text { range, 36.3-70.4) }\end{array}$ & $86.9 \pm 10.3(73.7-100)$ & NR & NR & NR & NR & Labial blisters $(\mathrm{n}=1)$ & $\begin{array}{l}\text { Second-look } \\
\text { arthroscopy owing to } \\
\text { mild persisting pain } \\
\text { at mean of } 16 \text { mo } \\
(\mathrm{n}=3) \\
\text { LT debridement ( } 1 \text { of } \\
\text { 3), and Capsule } \\
\text { retightening ( } 1 \text { of } 3 \text { ) }\end{array}$ \\
\hline $\begin{array}{l}\text { White et al. }{ }^{11} \\
\qquad(2018)\end{array}$ & 58 & 100 & NR & NR & $\begin{array}{l}\text { Rest, } 3 \\
\text { Activity, } 3 \\
\text { Athletics, } 5\end{array}$ & $\begin{array}{l}\text { Rest, l } \\
\text { Activity, l } \\
\text { Athletics, l }\end{array}$ & None & None \\
\hline $\begin{array}{l}\text { Hammarstedt } \\
\text { et al. } .^{33}(2015)\end{array}$ & 36.3 & $\begin{array}{l}3 \mathrm{mo}, 73.6 \\
12 \mathrm{mo}, 90.1\end{array}$ & 27.5 & $\begin{array}{l}3 \mathrm{mo}, 61.3 \\
12 \mathrm{mo}, 50\end{array}$ & 8 & $\begin{array}{l}3 \mathrm{mo}, 2 \\
12 \mathrm{mo}, 0\end{array}$ & None & None \\
\hline $\begin{array}{l}\text { Philippon et al. }{ }^{26} \\
\text { (2012) }\end{array}$ & $\begin{array}{c}52.7 \\
\text { (range, 47-59) }\end{array}$ & $\begin{array}{c}6 \mathrm{mo}, 53.5(40-67) \\
12 \mathrm{mo}, 61.3(40-74) \\
24 \mathrm{mo}, 75(54-96) \\
36 \mathrm{mo}, 82(68-96)\end{array}$ & NR & NR & NR & NR & None & $\begin{array}{l}\text { Resurfacing } \\
\text { arthroplasty at } 15 \text { mo } \\
(\mathrm{n}=1) \\
\text { Lysis of adhesions at } \\
6 \text { mo }(\mathrm{n}=1) \\
\text { Iliopsoas tendon } \\
\text { release at } 12 \mathrm{mo}(\mathrm{n}= \\
\text { 1) }\end{array}$ \\
\hline $\begin{array}{l}\text { Amenabar and } \\
\text { O'Donnell } \\
\text { (2012) }\end{array}$ & 53 & 100 & 73 & 95 & NR & NR & Suture abscess $(\mathrm{n}=1)$ & $\begin{array}{l}\text { Suture removal with } \\
\text { arthroscopic joint } \\
\text { irrigation at } 15 \mathrm{mo} \\
(\mathrm{n}=1)\end{array}$ \\
\hline $\begin{array}{l}\text { Simpson et al. } \\
\quad(2011)\end{array}$ & NR & NR & 42 & $\begin{array}{r}1.5 \mathrm{mo}, 72 \\
6 \mathrm{mo}, 86 \\
8 \mathrm{mo}, 89\end{array}$ & NR & NR & None & None \\
\hline
\end{tabular}

NOTE. Data are presented as mean \pm standard deviation unless otherwise indicated.

LT, ligamentum teres; mHHS, modified Harris Hip Score; NAHS, Non-arthritic Hip Score; NR, not recorded; THA, total hip arthroplasty; VAS, visual analog scale. 


\section{Studies}

Simpson et al. 2011

Amenabar et al. 2012

Philippon et al. 2012

Hammarsted et al. 2015

White et al. 2018

O'Donnell et al. 2020

Rosinsky et al. 2020

Overall $\left(I^{\wedge} 2=49.97 \%, P=0.06\right)$
Estimate (95\% C.I.) Ev/Trt

$\begin{array}{lll}0.25(0.00,0.85) & 0 / 1 \\ 0.75(0.15,1.00) & 1 / 1 \\ 0.88(0.55,1.00) & 3 / 3 \\ 0.25(0.00,0.85) & 0 / 1 \\ 0.25(0.00,0.85) & 0 / 1 \\ 0.33(0.03,0.64) & 3 / 9 \\ 0.22(0.00,0.49) & 2 / 9 \\ & & \\ 0.43(0.20,0.66) & 9 / 25\end{array}$

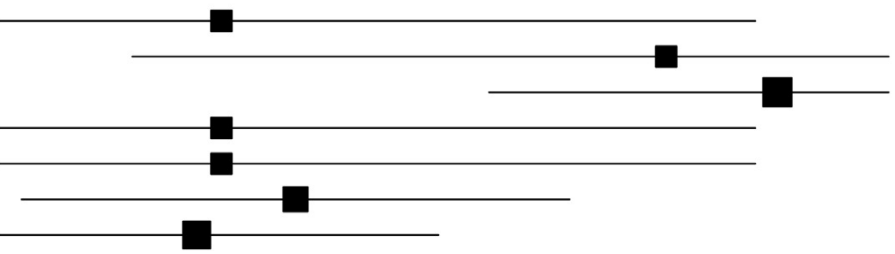

$9 / 25$

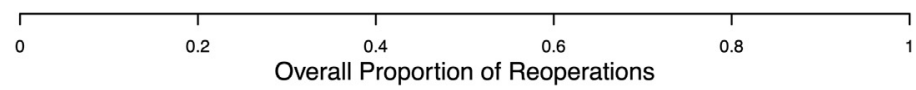

Fig 2. Forest plot of proportions for incidence of reoperations after ligamentum teres reconstruction. (CI, confidence interval, Ev, events [total number of patients undergoing reoperation], Trt, treatment [total number of patients treated].)

posteroinferior quadrant of the cotyloid fossa. ${ }^{11,26,32,34,35}$ This location corresponds with the insertion point of the more robust bundle of the LT and allows for safe drilling and graft fixation along the medial aspect of the quadrilateral plate while avoiding injury to the obturator neurovascular bundle. ${ }^{2}$ As a result, tunnel placement and fixation in the anterosuperior or anteroinferior quadrants are generally avoided owing to the proximity of the neurovascular bundle. ${ }^{2}$ The use of anchors has also been advocated over endopelvic buttons because of concerns for potential vascular or neurologic injuries due to the required "flipping" of the buttons on the medial surface. $^{32}$ Moreover, the use of biocompatible anchors may be advantageous over buttons because of the potential for biological incorporation into the acetabulum, theoretically improving fixation strength. ${ }^{36}$ Further investigations directly comparing the biomechanical properties and outcomes of acetabular fixation between anchors and buttons, as well as knotted and knotless anchors, are required to better understand differences in graft fixation to the acetabulum after LTR.
Furthermore, the patients included in this review were heterogeneous and likely differ in clinically meaningful ways. For example, $68 \%$ (19 of 28 hips) were revision cases; graft choice, fixation, and concomitant procedures were variable; and most patients were female patients. These findings limit the validity of conclusions and preclude us from providing definitive recommendations on LTR.

EDS is a genetic disorder affecting the structural integrity of collagen, manifesting with increased ligament elasticity and hypermobility, predisposing patients to joint pain, instability, and subsequent injury. ${ }^{37,38}$ Moreover, EDS patients represent a treatment challenge because of concerns for persistent or iatrogenic instability after hip arthroscopy despite correction of labral pathology, capsular laxity, and osseous abnormalities, which may be attributed to unaddressed LT pathology. ${ }^{24,39,40}$ It is interesting to note that $25 \%$ of the patients included in this systematic review had a diagnosis of EDS. Despite a paucity of reported outcomes in patients with EDS, mixed results have been documented in patients undergoing LTR. In their series,

\begin{tabular}{|c|c|c|c|c|}
\hline Studies & Estima & ate $195 \%$ & C.I.) & Ev/Trt \\
\hline Simpson et al. 2011 & 0.25 & $(-0.35$, & $0.85)$ & $0 / 1$ \\
\hline Hammarstad et al. 2015 & 0.25 & $(-0.35$, & $0.85)$ & $0 / 1$ \\
\hline White et al. 2018 & 0.25 & $(-0.35$, & $0.85)$ & $0 / 1$ \\
\hline Rosinksy et al. 2020 & 0.22 & $(-0.05$, & $0.49)$ & $2 / 9$ \\
\hline Subgroup $0\left(\left.\right|^{\wedge} 2=0 \%, P=1.00\right)$ & 0.23 & $(0.02$, & $0.45)$ & $2 / 12$ \\
\hline Amenabar et al. 2012 & 0.75 & $(0.15$, & $1.35)$ & $1 / 1$ \\
\hline Philippon et al. 2012 & 0.88 & $(0.55$, & $1.20)$ & $3 / 3$ \\
\hline O'Donnell et al. 2020 & 0.33 & $(0.03$, & $0.64)$ & $3 / 9$ \\
\hline Subgroup $1\left(\left.\right|^{\wedge} 2=6597 \%, P=0.05\right)$ & 0.63 & $(0.25$, & $1.02)$ & $7 / 13$ \\
\hline Overall (|^2=49.97\% \% P=0.06) & 0.43 & $(0.20$, & $0.66)$ & $9 / 25$ \\
\hline
\end{tabular}

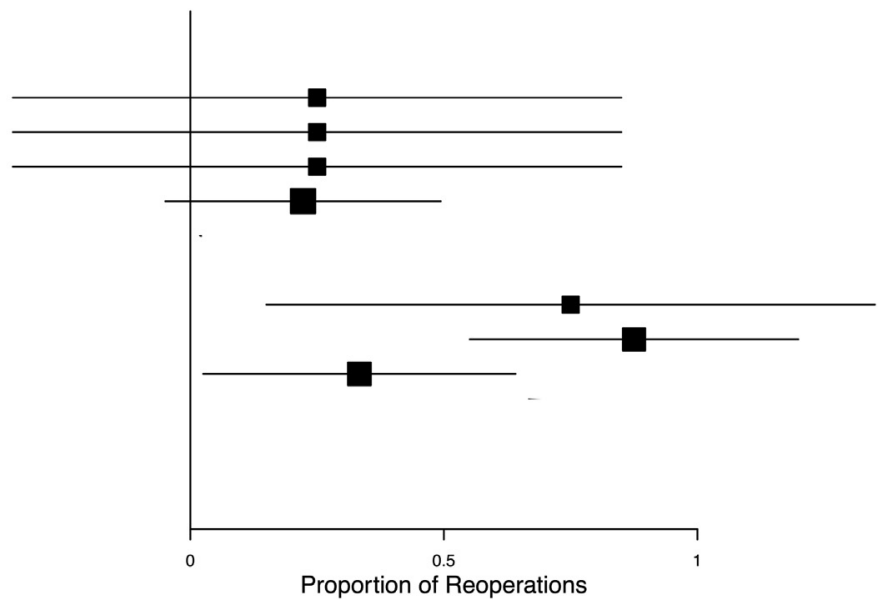

Fig 3. Forest plot showing differences in reoperation incidence between button (subgroup 0) and anchor (subgroup 1) fixation to acetabulum. (CI, confidence interval, Ev, events [total number of patients undergoing reoperation], Trt, treatment [total number of patients treated].) 


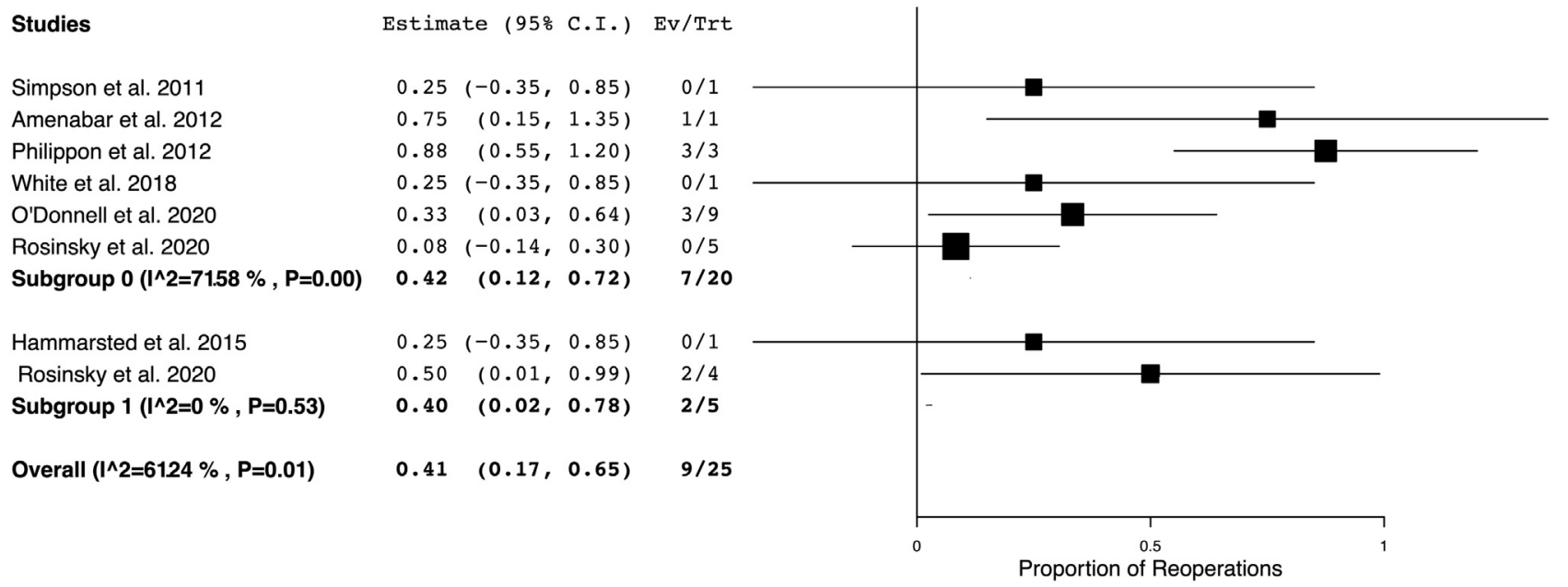

Fig 4. Forest plot showing differences in reoperation incidence between patients classified as athletes (subgroup 0) and those classified as non-athletes (subgroup 1). (CI, confidence interval, Ev, events [total number of patients undergoing reoperation], Trt, treatment [total number of patients treated].)

Rosinsky et al. $^{30}$ reported outcomes after LTR in 7 patients with EDS, 3 of whom had undergone prior hip arthroscopy with labral repair and capsular plication with continued pain and instability. Although satisfactory outcomes were reported in 4 patients, 2 patients required conversion to total hip arthroplasty at a mean of 21.1 months after LTR whereas 1 patient was noted to have not met the minimal clinically important difference threshold for the mHHS. In patients with ligamentous laxity with complaints of hip pain and instability, the LT warrants evaluation and consideration for reconstruction, especially in those with failed prior hip arthroscopy.

Owing to the repetitive loading and shear stresses placed across the hip during activity, as well as participation in activities requiring supraphysiological range of motion of the hip, athletes have been reported to possess a high incidence of FAI. ${ }^{41,42}$ As a result, athletic patients have been reported to show some of the highest rates of pathology to the LT. ${ }^{17,43-45} \mathrm{~A}$ retrospective review by Philippon et al. ${ }^{43}$ found that among 45 professional athletes with FAI undergoing hip arthroscopy, LT pathology was found in 65\% (29 of $45)$. Partial LT tears were found in $58 \%$ of athletes, whereas complete LT tears were diagnosed in $7 \%$. Meanwhile, an investigation of professional hockey athletes found LT pathology in $93 \%$ of athletes (26 of 28) undergoing hip arthroscopy for FAI. ${ }^{44}$ Haviv and $\mathrm{O}^{\prime}$ Donnell ${ }^{46}$ noted that patients at greatest risk of LT tears were young female individuals involved in activities requiring extreme range of motion of the hip, namely gymnastics and ballet. Although no difference in the reoperation incidence was appreciated when athletes were compared with non-athletes after LTR, a

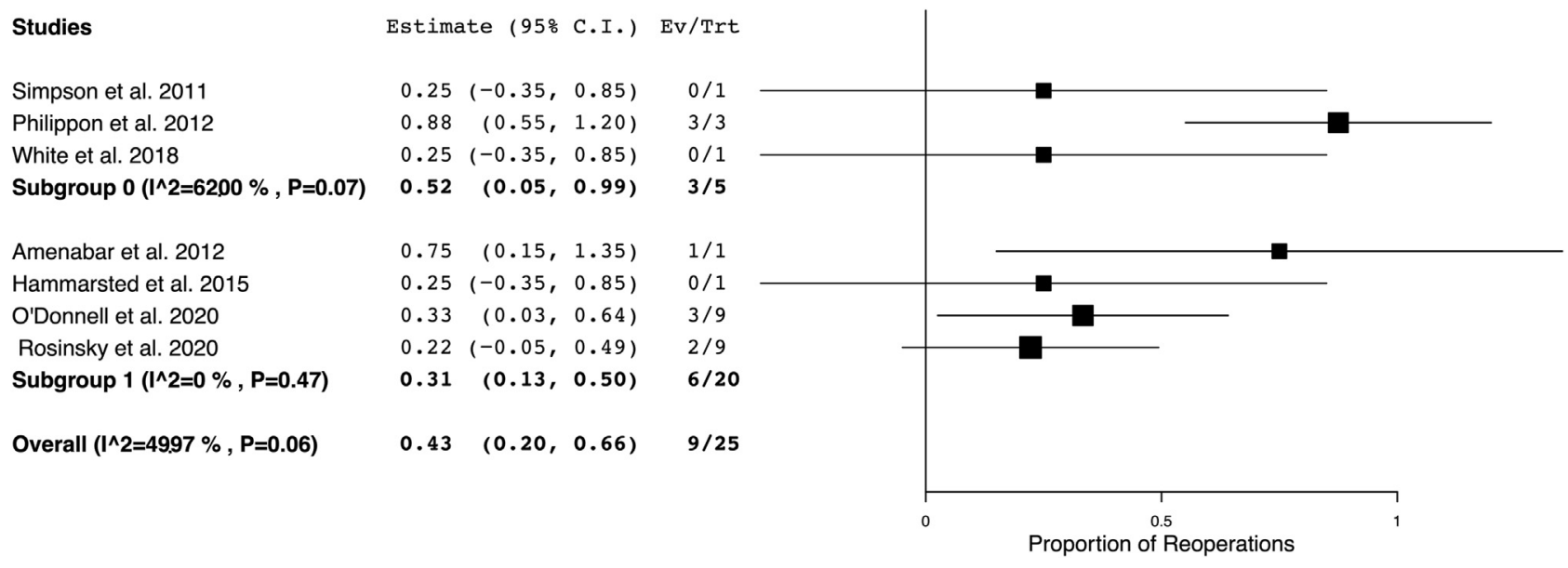

Fig 5. Forest plot showing differences in reoperation incidence between patients without Ehlers-Danlos syndrome (EDS) (subgroup 0) and those with EDS (subgroup 1). (Ev, events [total number of patients undergoing reoperation], Trt, treatment [total number of patients treated].) 
high suspicion of LT injury must be considered in athletic patients with hip pain and concurrent FAI undergoing hip arthroscopy.

\section{Limitations}

This study was not without limitations. As with all systematic reviews, publication bias may have influenced study results because largely positive outcomes were reported. All but 3 of 28 hips included in this systematic review came from female patients, so the findings may not be directly applicable to male patients receiving LTR. Furthermore, owing to the inherent nature of an experimental procedure such as LTR, only a relatively small number of patients could be reported in each study, preventing the opportunity for randomization and thus predisposing to selection bias. Moreover, this systematic review consists of heterogeneous studies with limited follow-up periods of 2 years or less and a low level of evidence (Level IV and $\mathrm{V})$, precluding a meta-analysis. LTR additionally is technically demanding, so the overall experience of the surgeon, as well as his or her skill level in this specific procedure, may bias the results and outcomes of these studies. The low incidence of reported LTR cases in the literature is also related to the low mean MINORS scores measured and small sample sizes. Prior investigations have identified higher rates of complete LT tears in patients aged 30 years or greater, ${ }^{19}$ female patients, ${ }^{17}$ and patients with a low body mass index ${ }^{17}$; however, because of the small number of identified cases, no meaningful statistical analyses could be performed to analyze the impact of these variables on outcomes. The direct impact of LTR on PROs is unknown and is likely confounded owing to the high prevalence of patients undergoing LTR performed concomitantly with other arthroscopic procedures. Moreover, we were unable to analyze outcomes based on graft type because of the failure in some studies to categorize outcomes based on the type of graft used. $^{30,31}$ Procedures performed during initial hip arthroscopy in patients requiring revision arthroscopy with LTR were infrequently reported and cannot be inferred based on the data provided in the included studies.

\section{Conclusions}

The main indication for LTR was persistent hip or groin pain and instability after a prior hip arthroscopy. The short-term postoperative mHHS, NAHS, and VAS score after LTR showed favorable outcomes. However, reoperations after LTR were not uncommon.

\section{References}

1. Martin RL, Palmer I, Martin HD. Ligamentum teres: A functional description and potential clinical relevance. Knee Surg Sports Traumatol Arthrosc 2012;20:1209-1214.
2. Rosinsky PJ, Shapira J, Lall AC, Domb BG. All about the ligamentum teres: From biomechanical role to surgical reconstruction. J Am Acad Orthop Surg 2020;28: e328-e339.

3. Perumal V, Techataweewan N, Woodley SJ, Nicholson HD. Clinical anatomy of the ligament of the head of femur. Clin Anat 2019;32:90-98.

4. Mikula JD, Slette EL, Chahla J, et al. Quantitative anatomic analysis of the native ligamentum teres. Orthop J Sports Med 2017;5:2325967117691480.

5. Dehao BW, Bing TK, Young JL. Understanding the ligamentum teres of the hip: A histological study. Acta Ortop Bras 2015;23:29-33.

6. O'Donnell J, Economopoulos K, Singh P, Bates D, Pritchard M. The ligamentum teres test: A novel and effective test in diagnosing tears of the ligamentum teres. Am J Sports Med 2014;42:138-143.

7. Botser IB, Martin DE, Stout CE, Domb BG. Tears of the ligamentum teres: Prevalence in hip arthroscopy using 2 classification systems. Am J Sports Med 2011;39:117S-125S (suppl).

8. Leunig M, Beck M, Stauffer E, Hertel R, Ganz R. Free nerve endings in the ligamentum capitis femoris. Acta Orthop Scand 2000;71:452-454.

9. Philippon MJ, Kuppersmith DA, Wolff AB, Briggs KK. Arthroscopic findings following traumatic hip dislocation in 14 professional athletes. Arthroscopy 2009;25:169-174.

10. Mandell JC, Marshall RA, Banffy MB, Khurana B, Weaver MJ. Arthroscopy after traumatic hip dislocation: A systematic review of intra-articular findings, correlation with magnetic resonance imaging and computed tomography, treatments, and outcomes. Arthroscopy 2018;34:917-927.

11. White BJ, Scoles AM, Herzog MM. Simultaneous acetabular labrum and ligamentum teres reconstruction: A case report. J Hip Preserv Surg 2018;5:166-173.

12. Papavasiliou A, Siatras T, Bintoudi A, et al. The gymnasts' hip and groin: A magnetic resonance imaging study in asymptomatic elite athletes. Skeletal Radiol 2014;43: $1071-1077$.

13. Mayes S, Ferris AR, Smith P, Garnham A, Cook J. Atraumatic tears of the ligamentum teres are more frequent in professional ballet dancers than a sporting population. Skeletal Radiol 2016;45:959-967.

14. Martin RL, Kivlan BR, Clemente FR. A cadaveric model for ligamentum teres function: A pilot study. Knee Surg Sports Traumatol Arthrosc 2013;21:1689-1693.

15. Register B, Pennock AT, Ho CP, Strickland CD, Lawand A, Philippon MJ. Prevalence of abnormal hip findings in asymptomatic participants: A prospective, blinded study. Am J Sports Med 2012;40:2720-2724.

16. Jo S, Hooke AW, An KN, Trousdale RT, Sierra RJ. Contribution of the ligamentum teres to hip stability in the presence of an intact capsule: A cadaveric study. Arthroscopy 2018;34:1480-1487.

17. Chahla J, Soares EA, Devitt BM, et al. Ligamentum teres tears and femoroacetabular impingement: Prevalence and preoperative findings. Arthroscopy 2016;32:1293-1297.

18. de Sa D, Phillips M, Philippon MJ, Letkemann S, Simunovic N, Ayeni OR. Ligamentum teres injuries of the hip: A systematic review examining surgical indications, 
treatment options, and outcomes. Arthroscopy 2014;30: 1634-1641.

19. Domb BG, Martin DE, Botser IB. Risk factors for ligamentum teres tears. Arthroscopy 2013;29:64-73.

20. Domb BG, Lareau JM, Baydoun H, Botser I, Millis MB, Yen YM. Is intraarticular pathology common in patients with hip dysplasia undergoing periacetabular osteotomy? Clin Orthop Relat Res 2014;472:674-680.

21. Maldonado DR, Laseter JR, Perets I, et al. The effect of complete tearing of the ligamentum teres in patients undergoing primary hip arthroscopy for femoroacetabular impingement and labral tears: A match-controlled study. Arthroscopy 2019;35:80-88.

22. Lodhia P, Gui C, Martin TJ, Chandrasekaran S, SuarezAhedo C, Domb BG. Central acetabular impingement is associated with femoral head and ligamentum teres damage: A cross-sectional matched-pair analysis of patients undergoing hip arthroscopy for acetabular labral tears. Arthroscopy 2018;34:135-143.

23. Martin RL, McDonough C, Enseki K, Kohreiser D, Kivlan BR. Clinical relevance of the ligamentum teres: A literature review. Int J Sports Phys Ther 2019;14: 459-467.

24. Domb BG, Stake CE, Lindner D, El-Bitar Y, Jackson TJ. Arthroscopic capsular plication and labral preservation in borderline hip dysplasia: Two-year clinical outcomes of a surgical approach to a challenging problem. Am J Sports Med 2013:41:2591-2598.

25. Amenabar T, O'Donnell J. Successful treatment of isolated, partial thickness ligamentum teres (LT) tears with debridement and capsulorrhaphy. Hip Int 2013;23:576-582.

26. Philippon MJ, Pennock A, Gaskill TR. Arthroscopic reconstruction of the ligamentum teres: Technique and early outcomes. J Bone Joint Surg Br 2012;94:1494-1498.

27. Liberati A, Altman DG, Tetzlaff J, et al. The PRISMA statement for reporting systematic reviews and metaanalyses of studies that evaluate health care interventions: Explanation and elaboration. J Clin Epidemiol 2009;62:el-e34.

28. Higgins JP, Thompson SG, Deeks JJ, Altman DG. Measuring inconsistency in meta-analyses. BMJ 2003;327:557-560.

29. Viechtbauer W. Conducting meta-analyses in $\mathrm{R}$ with the metafor package. J Stat Software 2010;36:48.

30. Rosinsky PJ, Annin S, Maldonado DR, et al. Arthroscopic ligamentum teres reconstruction: Minimum 2-year patient-reported outcomes with subanalysis of patients with Ehlers-Danlos syndrome. Arthroscopy 2020;36: 2170-2182.

31. O'Donnell J, Klaber I, Takla A. Ligamentum teres reconstruction: Indications, technique and minimum 1-year results in nine patients. J Hip Preserv Surg 2020;7:140-146.

32. Amenabar T, O’Donnell J. Arthroscopic ligamentum teres reconstruction using semitendinosus tendon: Surgical technique and an unusual outcome. Arthrosc Tech 2012;1: el69-el74.

33. Hammarstedt JE, Redmond JM, Gupta A, Domb BG. Arthroscopic ligamentum teres reconstruction of the hip in Ehlers-Danlos syndrome: A case study. Hip Int 2015;25: 286-291.

34. Simpson JM, Field RE, Villar RN. Arthroscopic reconstruction of the ligamentum teres. Arthroscopy 2011;27: 436-441.

35. Brady AW, Chahla J, Locks R, et al. Arthroscopic reconstruction of the ligamentum teres: A guide to safe tunnel placement. Arthroscopy 2018;34:144-151.

36. Menge TJ, Mitchell JJ, Briggs KK, Philippon MJ. Anatomic arthroscopic ligamentum teres reconstruction for hip instability. Arthrosc Tech 2016;5:e737-e742.

37. Stanitski DF, Nadjarian R, Stanitski CL, Bawle E, Tsipouras P. Orthopaedic manifestations of Ehlers-Danlos syndrome. Clin Orthop Relat Res 2000;376:213-221.

38. Lawrence EJ. The clinical presentation of Ehlers-Danlos syndrome. Adv Neonatal Care 2005;5:301-314.

39. Domb BG, Philippon MJ, Giordano BD. Arthroscopic capsulotomy, capsular repair, and capsular plication of the hip: Relation to atraumatic instability. Arthroscopy 2013;29:162-173.

40. Mei-Dan O, McConkey MO, Brick M. Catastrophic failure of hip arthroscopy due to iatrogenic instability: Can partial division of the ligamentum teres and iliofemoral ligament cause subluxation? Arthroscopy 2012;28:440-445.

41. Knapik DM, Gaudiani MA, Camilleri BE, Nho SJ, Voos JE, Salata MJ. Reported prevalence of radiographic cam deformity based on sport: A systematic review of the current literature. Orthop J Sports Med 2019;7: 2325967119830873.

42. Agricola R, Heijboer MP, Ginai AZ, et al. A cam deformity is gradually acquired during skeletal maturation in adolescent and young male soccer players: A prospective study with minimum 2-year follow-up. Am J Sports Med 2014;42:798-806.

43. Philippon M, Schenker M, Briggs K, Kuppersmith D. Femoroacetabular impingement in 45 professional athletes: Associated pathologies and return to sport following arthroscopic decompression. Knee Surg Sports Traumatol Arthrosc 2007; 15:908-914.

44. Philippon MJ, Weiss DR, Kuppersmith DA, Briggs KK, Hay CJ. Arthroscopic labral repair and treatment of femoroacetabular impingement in professional hockey players. Am J Sports Med 2010;38:99-104.

45. Kaya M, Suziki T, Minowa T, Yamashita T. Ligamentum teres injury is associated with the articular damage pattern in patients with femoroacetabular impingement. Arthroscopy 2014;30:1582-1587.

46. Haviv B, O'Donnell J. Arthroscopic debridement of the isolated ligamentum teres rupture. Knee Surg Sports Traumatol Arthrosc $2011 ; 19: 1510-1513$. 